\title{
From environment to culture: Aspects of continuity
}

\author{
Guido Ipsen \\ Faculty of Cultural Studies, University of Dortmund \\ Emil-Figge-Str. 50, D-44221 Dortmund, Germany \\ e-mail: guido.ipsen@uni-dortmund.de
}

\begin{abstract}
The conceptualization of the lifeworld of any species includes a reformation of the matter found in the environment into concepts which make up the species-specific Umwelt. This paper argues that the human agency in conceptualising the Umwelt necessarily transforms what we usually call "nature" into so-called "culture". Ultimatively, this human activity has two consequences which we cannot escape, but which have an influence not only on our perception of the environment, but also on our theorising about what has been called the "nature-culture divide", the "semiotic threshold" respectively: First, any environmental perception is at once conceived of in cultural terms. Second, whatever "nature" may be, our including it into the cultural discourse removes it from our immediate cognition.
\end{abstract}

\section{Some fundamental thoughts about the nature of nature}

There are various ways in which the human species connects what it calls nature with what is termed culture. In our everyday lives we are pretty sure where to find nature and where to detect culture. Two extreme oppositions are, e.g., an untended wild patch of forest, which is located towards the nature pole, versus a building constructed from glass, metal, and shining marble, which is a highly sophisticated cultural artefact. Doubtlessly, it is this open distinction; the experiential, i.e., the visual, tactile, acoustic, and other perceptible signs, which in the first case seem to come into being without human interference, and in the latter case are exclusively human in origin, which lead us to make a distinction between nature and culture also on higher, scien- 
tific levels. At the same time, we cannot but accept the fact that all materials that we use to create cultural artefacts do come from a "natural sphere". Still, in order to show that there is no divide between nature and culture, it is not enough to insist that the stuff culture is made of is natural. The ultimate bridge between the two realms is conceptual, and it is rooted in the very practice by which we transform our environment into our species-specific Umwelt.

In order to show the mechanics of conceptual transformation of nature into culture, I shall make use of Jakob von Uexküll's theory of the functional circle. Admittedly, in doing so I avoid the natureculture divide only seemingly. As we will see later, a divide between nature and culture that was existent for us as a species must exist inside our Umwelt. Following John Deely (2001), I suggest that there is a threefold division of "spheres" in our universe. First, there is the environment, from which we draw the raw matter which we later transform into signs. Of the environment, we cannot be sure. We shall never know in how far the environment is factual or not. There are, however, two spheres of which we are at least conscious and from which we derive our reflections. These are the spheres of the objective and the subjective. I do not want to go into detail concerning the divisions between subject world and object world here. Suffice it to say in the context of this paper that both the objective and the subjective play out by making use of signs. This means that both are already situated inside the human Umwelt. The Umwelt is cognitively separated from the environment. I suggest that any of the nature concepts that we encounter in popular or scientific discourse is already a transformation of matter from the environment into our Umwelt. Hence, these nature concepts are part of culture indeed, as all of our concepts are governed by our species-specific traits, which are naturally cultural.

As mentioned above, recognising our nature concepts as being part of culture only seemingly bridges the divide between nature and culture. "Real", or "true" nature must be situated where culture has no rule, which ultimatively means that nature should be completely detached from culture. In my reasoning, culture is the one force that enables us to chart our Umwelt, meaning that "true" nature can only exist where culture does not execute this force. Nature, if we insist on using this term for something non-cultural, would hence logically be removed to the general sphere of the environment. For purposes of investigating objects or species that are different from humans, it may 
be useful to employ the term nature also as part of our Umwelt. Still, we must be conscious of the fact that any concept we use for said objects or species is already cultural. This is the ultimate deconstruction of the nature-culture divide.

At the same time, this conception of nature as something being part of the general environment allows us to define an individual semiotic sphere for any species, equalling their species-specific Umwelt. Insofar, the environment, or nature for that matter, are resources for semiosis not only for humans, but also for other species. Again, Jakob von Uexküll's functional circle allows us to define such individual spheres of semiosis. As you will notice, in this line of thinking it seems that, e.g., the Umwelt of a tiger would be removed from nature as is the human's. From our perspective, this seems ridiculous, as we consider tigers to be part of nature. In exemplifying my above ideas, let me rephrase the relations as follows: The human agent takes the tiger for something "natural". By attributing the term "tiger" to the animal, the latter is, however, at once culturalised. The term tiger, its connotations, denotations, and any further acts of semiosis where it is included play out on the cultural level. For the tiger, however, different acts of semiosis are important in order to construct his Umwelt. For him, nature or culture as terms are completely irrelevant. Still, his conceiving of other animals, e.g., a human, as prey, is already a species-specific reinterpretation of the environment. Hence, the same principles apply to human or tiger perception of the environment. Let us now take a closer look on how our conception of nature being separated from culture is structured.

\section{The semiotic paradox of divides}

The habit of taking on material from natural resources to the human body in order to produce clothing for shelter, accessories for decorative purposes, tools, or weapons, is as old as human culture. But does this practice indeed make up a divide between this so-called exclusive human domain and nature? Is there really a dividing line between semioticised material within culture and the unused matter beyond? An argument in favour of this divide was that the said materials only gain the value of signs as soon as they are being used by the standards of cultural signification (Eco 1976: 21). The whole argument ulti- 
mately boils down to the question of whether a nonsemiotic world exists, by its very existence defining the more sophisticated, however somewhat smaller cultural domain. This question can be pursued in two ways. First, we could try to prove that there is a nonsemiotic world by finding something that has yet not gathered the value of a sign. The second way of defining the nonsemiotic is to state that there are beings in a biological world whose perceptions, communication, and lives are not meeting the standards of semiosis as we find it in humans. Let us explore these two lines of reasoning first.

\subsection{The nonsemiotic world of items}

Instead of item, we may also use the terms "thing", "object", or "material". Nearly all terms, however, have been introduced to one cosmological model or another. Appropriate terminology therefore is difficult to approach. What here is called items is that which is defined as "not (yet) being a sign". What are "non-signs"? I admit that this paper challenges the existence of non-signs altogether. I suspect that they are a theoretical construction to introduce yet another negative definition of what signs are. According to Saussure, e.g., the nonsemiotic world is an "uncharted nebula" (1916: 111-112). This is a negative definition par excellence, and also a genial delimitation of theorizing: It defines everything known as signs, and at the same time spares Saussure to actually name something which is not a sign. As we will see later, Saussure's approach bears some similarity to this paper's arguments, as there clearly are areas and things in the world which are not known to us. We know of the unknown and if only for the reason that our measuring apparatus has been able to penetrate some of the vast unknown of the universe, leaving yet uncharted areas behind the final frontier. Still, the postulation that whatever matter is unknown remains in a "nebula" of non-signs is a hypothesis only serving for reassuring us of the significant value of our knowledge. Moreover, it reduces semiotic theory to mere anthropocentrism.

For another example, St. Augustine (397: 624-625; cf. Nöth 1990: 82 ) gives a more clear account of what non-signs are. He makes a difference between "signs" and "things". Keeping close to the definition of a sign as something which stands for something else, i.e., aliquid pro aliquo, he lists items such as "wood, stone, cattle or other things 
of that kind" as non-signs. Nöth calls this approach "naïve realism". Indeed, here the question must be raised again if a sign will only be a sign if it will be sorted with other, similar signs, in a system appropriate to human understanding. Also, does the sign cease to be a sign if appearing out of this systemic context? Clearly, wood, stone and cattle can take on most diverse sign values. We will discuss the case of living creatures later on. Concentrating here on the examples of wood and stone suffice it to say that they already gained sign value as soon as St. Augustine listed them as specimen of non-signs: Wood or stone standing for non-signs, they paradoxically become signs for non-signs.

Another well-known approach, which has also been employed for dividing the cosmos into the spheres dominated by humans and other creatures, is the one devising the so-called semiotic thresholds. Umberto Eco (1976: 16-28) employed the term of the threshold to delimit the semiotic field. The interesting aspect here is that it is the methodological and disciplinary perspective of a semiotic science which governs the view of the cosmos. Below the lower semiotic threshold, there are those phenomena not guided by social convention, delimiting the semiotic field to the socio-cultural sphere. Beyond the upper semiotic threshold, according to Eco, there are those phenomena studied by other sciences than semiotic. Most interestingly, Eco sees any possible object as attached with semiotic as well as nonsemiotic value. As soon as something is studied as a sign, it becomes subjected to the semiotic field. If the same item is then studied as, say, a tool, it drifts from the semiotic field and is confined to the sphere beyond the upper semiotic threshold. Concerning Eco's semiotic thresholds, it is most noteworthy that his third threshold is neglected in all reflection on the subject matter. Eco calls this third threshold the epistemological, and as I take it, this is the inspiring force behind all threshold thinking. The first and the second threshold explain how the semiotic field may be delimited. These limits seem to originate from an intrinsic semiotic reflection. The third threshold, however, explains that there is in truth an extrinsic reason for delimitating the semiotic field in the first place. Semioticians seem to be afraid to admit that semiotic has no field except maybe the realm of pure thought, as Peirce sometimes reflects (cf. CP 4.6). Indeed, as soon as we apply semiotic theory to any subject matter, semiotic becomes involved with other disciplines. So it must be, as beyond their mental nature, signs do signify perceptions that are usually investigated by said other disciplines. This makes se- 
miotic a transdiscipline as such, but yields the disadvantage of attributing no specific field to it. It is therefore understandable that Eco feared to admit the true nature of semiotic and confined it to the study of culture instead. This is indeed a political decision, not a semiotic one.

While it is only obvious to acknowledge that the field of, e.g., physics, sports, mathematics, etc. is separated from the semiotic field if seen from the perspectives of the monodisciplinary physicist, sportsman, or mathematician (these not calling themselves semioticians $^{1}$ ), I should argue that the schizophrenic nature of items as Eco sees them is not given. As soon as semiotic puts itself to the task of examining anything according to its sign value, this item cannot ever again disappear from the semiotic field. Neither can the semioticians see an item oscillating between the semiotic and the non-semiotic, or else they were disregarding their own discipline. In other words: Whereas any other (possibly merely ignorant) person may not see things as semiotic, they must be so for the semiotician. In any other case, semiotic would be reduced to an alternative science that had not even the field of thought for its own.

While I do not only embrace but admit the possible accusation of pansemiotism here, my main objection against the upper semiotic threshold is especially nurtured by Eco drawing disciplinary borders. His division between semiotic and nonsemiotic remains artificial and is already guided by cultural propositions, for clearly the concept of disciplinary fields is not inspired by nature as such. Semiotic, however, should be seen as a transdiscipline par excellence, as such busying itself with signs from any field of human knowledge.

\footnotetext{
1 Note, however, that the point has been made that there are not only explicit studies of semiotic, which would cover the theories of the sign proper, but also implicit semiotic, which "covers the many semioticians avant la lettre who have contributed to the theory of signs since Plato and Aristotle but also includes semiotically relevant current studies in the many neighboring fields of semiotics", as Nöth (1990: 4) remarks. In accordance with Peirce, I hold the limits of these neighboring fields as virtually nonexistent. In this judgment I follow his intention to "outline a theory so comprehensive that $[. .$.$] the entire work of human reason$ [...] shall appear as filling up of its details". In this regard, physics, sports, and mathematics are fields of semiotic. For the example of sports, see e.g., Hildenbrandt (1997), Bockrath (2001), Friedrich (2001) and the special issue of the Zeitschrift für Semiotik 19(4), 1997, on the topic.
} 


\subsection{The nonsemiotic world of beings}

In the realm beneath the lower semiotic threshold, we find the processes of communication in animals and plants. While the upper threshold of Eco's is a rather disciplinary border, as mentioned above, the lower one definitely separates biological life from the human sphere of signification. This second divide hence does not yet separate the body from its environment, but the cultural from the natural sphere. Everything above that threshold, according to Eco, in the realm of culture, is coded in a specific, cultural way. Naturally, the question is what "culturally coded" means. The point has been made that by discovering more and more sophisticated sign systems in the realm of animals, or even plants, the semiotic threshold has been lowered and is being lowered still. I do not wish to go into the question of whether animals are capable of producing signs and to observe signifying actions in a way comparable to human custom. This would be a completely different endeavor beyond the scope of this paper (but compare Martinelli 2002, for a detailed analysis of this subject matter).

More detailed work on the delimitations of the cultural has been done by Lotman, who admittedly was not so much interested in excluding animal and plant life from human culture rather than defining the possible limitations of the latter. We must, in contemplating these differences, keep in mind the binary, or dyadic, fundament of Russian semiotic. A thorough study of Lotman's work therefore will reveal that the limitations of culture also comprise the limits between various strands of culture, and most notably those between the own and the foreign, thus creating structural dichotomies as models. The space of culture in Lotman's theory is called the semiosphere, contrasting the biosphere of biological life (Lotman 1990: 125). The important features of culture are communication, language, and the intricate means of using these to trade culture to following generations (Lotman 1990: 124; see also Lotman 1981: 125; and cf. Nöth 2000: 133).

The borders between the semiosphere and the non-semiotic may, however, also be understood as the borders between the signs already culturally coded and those not yet culturally coded. Such a division would render the entire universe semiotic, true to Peircean theory, and would hence differentiate only between certain types of coding: Cul- 
tural and non-cultural. ${ }^{2}$ The possibility of dividing the world into these domains must remain questionable, however (cf. Nöth, Kull 2001).

Another point made by Lotman (1981: 26-27) concerns the rules and methods of how information is stored and communicated by culture. Certainly there are distinct differences here between "culture" and "mere biological life". I do not wish to argue against it. However, sign processes will transcend the borders, and culture, too, depends on the biological processes which support cognition and mental activity. There is not possibly any culture without biological life, and in order to function properly and interact with the surrounding world, a culture will have to incorporate biological life from the so-called non-semiotic world substantially. The process of semiosis therefore transcends the nature-culture divide and requires a redefinition of the various semiotic spheres which constitute the universe.

The semiosphere is externally constituted by that which is not in agreement with the coded structures within (Lotman 1990: 131-142). Nöth (2000: 133) explains that there can be semiotic space within and without the semiosphere; however, it seems that the emphasis on culture denies that there are semiospheres to be assumed in nature, hence the contrasting term biosphere. In the biosphere, we may assume by negating Lotman's characteristics of the semiosphere, there is no information not inherited, there are no specialised means to organise information, and there are no rules to determine the overall system of information communication (cf. Lotman 1981: 26-27). It is exactly this terminological emphasis on communication which renders the biosphere so obscure, as "language" is the basis for cultural action, and the "social conflicts" and the "semiotic systems" located in the semiosphere are the cultural "messages" which are formulated in "texts" (cf. Lotman 1981: 27-29), so leaving the seemingly nonlinguistic biosphere behind. This logocentrist view on culture has the unfortunate effect that it draws a definite border which is difficult to overcome. Following these lines of argumentation, a linguistic basis

\footnotetext{
2 I prefer to avoid the term "natural" here, as this would imply that there be a coding system of nature similar to a coding system of culture. Truly, there are many other coding systems; either they should be summarized under the label "nature", including culture, or the term nature should be avoided. As this paper argues, there can be no nature-culture dyad. Both are intertwined and form the unity of the cosmos.
} 
of coding would have to be found in the biosphere so to qualify it for semiotic consideration. ${ }^{3}$

\subsection{Dissolutions of the semiotic-nonsemiotic divide?}

There are several semiotic approaches that may serve to either weaken or even overcome the divides between the semiotic and the nonsemiotic. One of the more traditional approaches to this aim is Greimas' text semiotic. He undertakes to give a possible definition of what "natural signs" (Greimas 1987: 20) could be. However, from the outset, Greimas does not move from the cultural sphere in his argumentation. His examples are strictly culture-governed: First, he mentions examples illustrating "cause and effect", such as a cloud signifying rain, rain in the cause signifying autumn and so forth, or the knee-jerk reflex signifying good health. Admittedly, Greimas agrees that these interpretations are bound to peculiar cultural spheres (Greimas 1987: 21). Still, he does not go so far as to admit that any phenomena may also attain sign value beyond culture whatsoever, hence a cloud resembling a physicosemiotic body in itself, or the knee-jerk reflex being a biosemiotic sign signifying a chain of sign events in the body without so much as a cultural interpretation being necessary in the first place. Greimas' approach may be acknowledged as a "bridge spacing the gap" between pansemiotism and anthroposemiotism, but it must be admitted that the semiotisation of the natural environment takes place in a "semiotics of nature based on cultural codes of interpretation of this environment" (Nöth 2000). This means the "natural world is only significant in a human-made way. Natural semiotic is

3 It should be pointed out here that the metaphor of the "text" that has been favored throughout the twentieth century by semioticians indeed lacks some qualities which are necessary to illustrate transcending sign systems. Texts are human artifacts, they are two-dimensional, they consist of one material only, namely whatever substance the threads of code consist of. The metaphor of the forest seems more appropriate. It shows many qualities of the view on sign systems used in this paper: Forests are natural, or they can be planted and hence be human made. The forest is made up by many different species, and even more interactions between them. Also, the forest consists of prominent signs and hidden signs. It is a mesh of signs much more complicated than a text, governed by a multitude of rules, and, last but not least, it will always transcend the cultural sphere into nature. 
rendered an exclusive result of the human codification of nature" (Nöth 2000; all quotes my translation, G. I.). Nöth calls this perspective "intersemiotic"; it should be pointed out, however, that the perspective remains anthropocentric, as Greimas himself declares: "A human world is detached from the totality of the "natural" world, which is what is specific to each cultural community. Only those events of the world which have people as subjects are part of such a semiotic; natural events (e.g., earthquakes) are excluded" (Greimas 1987: 30). Greimas "natural semiotics" therefore is less a bridge between the semiotic spheres than a proof of the thesis of this paper, namely that any contemplation of the natural world, regardless of its independent semiotic value, must result in a culturalisation of the natural.

A theory truly dissolving the semiotic-nonsemiotic divide is Peirce's approach. He claims that "all this universe is perfused with signs, if it is not composed exclusively of signs" (CP $5.448 \mathrm{fn}$ ). This remark has been widely disputed, especially in regard of the question whether everything really can be a sign. Again, I shall not venture into this discussion here. It is, however, fundamental that by the process of signification, where from firstness via secondness to thirdness all signforms may appear, the variety of signs reaches far beyond those bound to convention. The latter, in Peircean terminology symbols, or legisigns, are just one of the many classes of signs he devises in his system. ${ }^{4}$

\subsection{Hybridization and the pansemiotic bridge}

Even if we pursue a course that clearly divides culture from nature, as, e.g., Umberto Eco did, we have to accept that a basic tendency of, e.g., using tools, is also existent in the world of animals. Otters use stones for breaking shells, chimpanzees "fish" ants by use of sticks, and many animals build shelters.

In these examples, we may see how the nature-culture divide is being weakened from below. At the same time, humans have continu-

4 From the many varying approaches Peirce takes to this subject matter, I may be so bold as to propose here that the Peircean classification of signs in itself is merely an artificial system devised by the great scholar in order to metaphorize his theory, which in itself is rather processual than class- or system-oriented. 
ously been extending the variety of resources nature offers. This inclusion of as yet protosemiotic ${ }^{5}$ matter into the process of cultural development produces hybrid artefacts. They are hybrid because they consist of so-called "natural" material - i.e., material that does not originally have cultural value or purpose - and a cultural concept of how to use the item. We must understand that this process started at the most archaic levels of evolution. Culture - in whatever terms we may define it - always carries a basic function. It helps the human being understand the cosmos by "humanizing" it. By this I mean that the items and material found in the cosmos are evaluated according to their uses and functions to the human being. ${ }^{6}$ They hence have a double sign value. First, the natural signs - which, I argue, do exist beyond the confines of our mind - interact on the foundations of natural laws, or relations beyond the obvious to the human mind. Second, items and materials gain a second sign value by their being taken on to human culture. This distinction being only existent in theory but both sign spheres occupying the same physical world, it is obvious that these signs must become hybridized.

From these preliminary thoughts it becomes clear that in discussing hybridity, the material form of items must not be the focus of investigation. Indeed, matter and concept together form a hybrid artefact. Hence, a stone in the field neglected by any passers-by is not a culturally hybrid item; still it has its proper place in the sign systems of minerals. It evinces form, radiation, and constituents which terminate its place in the cosmic evolution. However, as soon as somebody

5 Protosemiotic here refers to possible-signs that are as yet non-signs only in regard to purely human signification. Indeed, for the human being — as I may add here for emphasis - signification is not only a possibility, it is a must, perhaps even a "curse". Humans will never be able to fully understand nonhuman signification, as they can not leave the cognitive apparatus of their species behind. Also, meaning for us is always given; even in producing new meaning, we must refer to existing ones (cf. Greimas 1966). The transformation of the protosemiotic to the semiotic adheres to the same principles, governed, however, by the rules of human signification alone. I should also like to agree with Nöth (2001: 14-15), who emphasizes that the acknowledgement of semiosic processes beyond the confines of culture goes along with the rediscovery of Peirce's concept of semiosis, a concept large enough to cover for much more than cultural signification.

6 Taking this argument literally, it follows that God was wrong when he asked Adam to give everything its proper name. He should rather have said that Adam was to give every item on earth its most appropriate name according to Adam's subjective view of the universe, so to conceptualize the world by human terms. 
picks up the stone for any purpose, the stone is immersed in human culture. Its pure "naturalness", if you allow for such a term, is ultimately lost. Its colour may now be regarded as beautiful, its mineral contents as valuable. Its form may appear useful as a wedge or a doorstopper or its heaviness as a weight. In this way, any item, material, or appearance in the universe may eventually become "culturalized".

The most prominent hybrid artefact in this sense is the human body itself. Hybridisation of the body is usually conceived of as being directed towards the appearance or composition of the body. Hybridization in these terms means taking on material to the body in order to intensify its beauty, to give it shelter, or to replace lost organs or limbs, i.e., replace them by prostheses, in order to maintain the functionality of the human body. All of these meanings of hybrid bodies are true of course. Nevertheless, hybridization of the body also involves the amalgamation of material and concept. The application of paint to the face does not produce beauty or significance automatically. Those colours, powders, and fragrances are culturally coded, as is the way the make-up is applied to eyelids, cheeks, or lips. In this example, we find hybridity in the appearance of the body.

As soon as it comes to more complicated examples such as sheltering the body, we find that concept and material are actually gradually moving away from the body into the semiotic sphere surrounding it. Shelter for the body may well mean clothing - something that indeed still changes appearance and composition of the body itself but it can also refer to a cave, or a house. In both cases, something is coded with a bodily function - namely, maintenance of temperature, protection from rain, etc. - yet not directly connected with the body. The bricks, beams, and tiles of the house are not a part of the body, neither is the rocky surface of the cave. Still, both are immersed into the bodily coded culture. The materials have been reimbodied in cultural contexts. In other words: Beyond their possible semiotic qualities in a hypothetically nonsemiotic nature, rock, wood, and stone are now part of the culturally coded interpretant. ${ }^{7}$

From this semiotic process of immersing nature into culture, two statements follow: First, hybridization of the body only begins with

7 This argument challenges the notion that a difference exists between usage and meaning; the point, however, already has been made by semiotic studies of commodities. Cf. Douglas, Isherwood (1979: 62); Csikszentmihalyi, RochbergHalton (1981); or Appadurai (1986). 
using stones as tools, or animal fur as clothing. Any habit, technology, or other cultural practice results in hybridization of the body and its Umwelt. In modernity, it has reached the level of melting metal from ore and refining plastics from oil, using sophisticated machines for calculation, firing rockets to the end of destruction, etc. Humans are thus able to produce prostheses for a large variety of uses in the human body. In this variety, both special cases, such as medical applications and everyday usage of materials in fashion or other fields are included. The consequence is the extension of the culture into nature, a result which makes it easier to understand the Umwelt, and at the same time reduces it, since the Umwelt becomes itself a part of the semiosic process within the interpreter.

The second statement follows from the first. If anything used by humans, if everything conceptualised, graded, considered, or calculated becomes part of the human culture, there is virtually nothing "purely natural" left in the universe, save for objects or concepts as yet unknown to humankind (and I do not refer here to, e.g., as yet unseen doors). For any theory depending on a nature-culture divide, this is an ultimate problem. Nature in itself, as long as it is by definition demanded to exist completely unattained by culture, would remain unobservable. This phenomenon may be described as the ecological paradox. Peircean semiotic, however, offers a valid solution to this problem, which I will try to sketch. The second statement draws on the fundamental notion of how the universe must be designed. Obviously, the universe is divided into those objects which are culturally coded and those which are not (and rendered unknown). In the process of human semiosis, the extensions of the human body have reduced those areas on the planet Earth which are excluded from that cultural coding to a little number, now comprising only the deepest depths of the oceans, several happy species of insects and plants, and the tiniest spaces of the microcosm. Man strives to also extend his sphere of knowledge to these. Nature has thus almost entirely been conquered by culture. This makes it hard to define the confines of "real" nature in the ecological or semiotic discourse. Whatever we speak of when referring to nature has long since been made part of our culture. Animals and plants, ores and minerals have acquired cultural value, indeed any attempt at excluding animals or plants from what is frequently called cultural behaviour can only result in paradoxically including, reimbodying, immersing these same animals and plants into 
culture, as necessarily they must be culturally coded - and graded before being able to serve as counterexamples.

The result of these thoughts is that we need to establish a pansemiotic view in order to understand the effects of cultural signification in the larger semiotic sphere which comprises the cosmos. Pansemiotism has been condemned by more conservative semioticians (cf. Nöth 2001: 15). Pansemiotism has thus almost become an accusation close to an insult. ${ }^{8}$ Nöth prefers to use it cautiously with a question mark. He argues that

to describe Peirce's universal semiotics as a pansemiotic theory is a gross simplification. Semiosis, in the framework of Peirce's theory, presupposes thirdness, but the world does not only consist of phenomena of thirdness, but also of phenomena of firstness and secondness, which are not yet semiotic phenomena, although they may have 'quasi-semiotic' characteristics, since Peirce's theory of continuity does not establish a mere dichotomy between semiosis and nonsemiosis, but distinguishes many transitions between genuine and degenerate quasi-semiosis. (Nöth 2001: 15)

I should like to focus on the point of continuity here. Indeed Peirce's thorough system of categories of signs and semiosic processes allows for two interpretations, the first of which would suit those semioticians who prefer to draw borders between nature and culture, semiotic and nonsemiotic and so forth. This interpretation would locate definitely quasi-semiosic processes below said semiotic thresholds, so to be neglected by semiotic. The second interpretation, which is preferable, should emphasize the continuous nature of Peirce's theory and allow us to neglect the existence of thresholds in the first place. We may thus create a pansemiotic bridge covering the gap between nature and culture which is the vehicle for an understanding of the transcendence of sign processes in the cosmos.

\footnotetext{
8 Some semioticians also despise the pansemiotic view for the same reasons Eco introduced his threshold: They require the concept of difference in order to specify semiotic. A colleague of mine once argued that "if everything is semiotic, semiotic does not exist", hence falling for the old trap of negative dyads. However, such thinking leads to unwelcome and inappropriate constructivism. For example, we do accept the existence of the universe although we know of nothing that is not the universe. Also, definition along the lines of Peircean thought should result in an additive reasoning, not a negative. Difference in Peirce is only located at the root of semiosis, not in its interpretative result.
} 


\section{The transformation of nature into culture}

We have seen that the concepts of division that are still existent in semiotic theory may be overcome by applying a theory of continuity. In the following, I should like to make use of two theoremes that exemplify how we culturalise, i.e., make part of our Umwelt the sign resources of nature. The first is the cosmological dimension of the theory of semiosis by Peirce, the second is the functional circle by von Uexküll.

\subsection{Sign formation on a cosmological scale: Peirce}

In the process of semiosis, Peirce well defines a process where the semiotic world cannibalises the non-semiotic world. Semiosis started from the point of utter chaos and will (ultimately but still hypothetically) result in a universe governed by the rule of thirdness. Peirce, however, does not speak of the universe as only consisting of signs if chartered by human thought. According to Peirce, as mentioned above, the entire universe is composed of signs. ${ }^{9}$

It is plural, not monadic systems which govern the universe and, following from that, human cognition. This is not a new insight, but has long been observed by the pragmatist tradition. Note, however, that "pluralism" does not exclusively focus on concepts such as difference. ${ }^{10}$ Rather, plurality is conceived of as a logical concept at the root of any cognition. The minimal form of plurality, namely binarity, is contained in any thought, as Peirce emphasizes. Each meaning is already a form of reaction:

\footnotetext{
9 Hence, a distinct and fundamental division has to be made between Peircean and Saussurean views of the universe. In the latter's conception, anything not coded by cultural signs remains vague and unchartered - virtually nonexistent. From Peirce's point of view, also forces of nature are in itself semiotic. He devised a complex variety of sign types for any possible phenomenon. Hence, if there was something nonsemiotic, according to Peirce such a thing or concept should not only be beyond our knowing of it, but also beyond any possibility of hypothetical existence.

10 Difference in plurality and hybridity does play a role in structuralist and/or poststructuralist theory, where the essence of sign relations will always depend on the exclusive position of a sign in a system which constitutes itself in difference to other signs in the system.
} 
We can make no effort where we experience no resistance, no reaction. The sense of effort is a two-sided sense, revealing at once a something within and another something without. There is binarity in the idea of brute force; it is its principal ingredient. For the idea of brute force is little more than that of reaction; and this is pure binarity. Imagine two objects which are not merely thought as two, but of which something is true such that neither could be removed without destroying the fact supposed true of the other. Take, for example, a husband and wife. Here there is nothing but a real twoness; but it constitutes a reaction, in the sense that the husband makes the wife a wife in fact (not merely in some comparing thought); while the wife makes the husband a husband. (CP 2.84)

The result of binarity, namely the relation between elements, naturally belongs to the category of secondness. It connects the phenomena of firstness (mere feelings yet bearing no true meaning), as without secondness nothing could be experienced:

The world would be reduced to a quality of unanalyzed feeling. Here would be an utter absence of binarity. I cannot call it unity; for even unity supposes plurality. I may call its form Firstness, Orience, or Originality. (CP 2.85)

This plurality inherent to the signs results from the process of semiosis, the principally endless chain of experiences leading to ever new signs which will again be incorporated into the process. Experience requires continuity, and continuity is a projection on the past: Experience is "esse in praeterito" (CP 2.84). As experience - as a result of semiosis - is found in the interpretant, or effect of the sign, plurality is an important criteria for thirdness: "The general idea of plurality is involved in the fundamental concept of thirdness, a concept without which there can be no suggestion of such a thing as logic, or such a character as truth" (CP 4.332). Hence, plurality means multitude in signs and thus in the cognisable world ("variety of nature", cf. CP $1.160 ; 8.307)$. The universe in itself $i$ s plural, its singular appearances are our own constructs. They do not lie in the nature of the universe itself:

In the little bit that you or I can make out of this huge demonstration [of the universe], our perceptual judgments are the premisses for us and these perceptual judgments have icons as their predicates, in which icons qualities are immediately presented. But what is first for us is not first in nature. The premisses of nature's own process are all the independent uncaused elements of facts that go to make up the variety of nature. (CP 5.119) 
In the words of this paper: Experience in essence is continuous. The "internal" and the "external" of the mind flow together in the signs; representamina of manifold kind, be they acoustic, pictorial, tactile, olfactory, etc., together form new interpretants.

If this plurality is active in all the universe, then the human mind is an agent of transformation. The relations between the elements of experience are established by the interpreters. Whatever becomes part of the human Umwelt must pass this agency. There cannot be an Umwelt without a mind, or an Umwelt without the environment.

\subsection{The construction of the Umwelt: von Uexküll}

Jakob von Uexküll devised a most comprehensive model of how a subject by receiving perceptions from the diverse environment constructs its own Umwelt. In his biological foundation of the model, he shows how the perceptual and effector organs are connecting the interior, subjective realm of the perceiver with the exterior environment. Uexküll's first aim is to show how the action and reaction of a subject in the environment is governed and at the same time restricted by its organic delimitations. Or, in other words, the organic setup of the subject meets its requirements to survive in the environment (Uexküll, Kriszat 1970: 6-14).

The object world in the functional circle makes itself "known" to the subject by the stimuli that may be perceived by the organism's receptors. The perceptual organ then processes the stimuli. As a result, the perceptual organ (in other words, the brain) returns a perspective on the environment that in due course causes a reaction, i.e., a speciesspecific action that fits the environmental setup. By reacting, the organism will also have an effect on the environment which is therefore changed and will henceforth be perceived differently (see Fig. 1).

Uexküll uses the very simple example of the tick in order to illustrate the various components of the functional circle. I should like to paraphrase here his terminology to the end of showing how humans reconstruct nature by means of culture. First, we must note that the receptors, the perceptual and effector organ, and the effector are each species-specific. This means that any species gains its own view on the environment that we may be able to reflect, but which we will never be able to fully comprehend or reconstruct (cf. Martinelli 2002). 
I argue that the human species-specific perspective is the cultural one. This means that any perception of the environment is turned into something cultural by the perceptual organ. The Umwelt of humans consists of elements that are part of our conceptual framework. Hence, we cannot see, e.g., trees as trees, or cattle as cattle. Even if we do not choose to perceive the former as the resource of wood and the latter as food, we cannot help but accept that both trees and cattle are part of classifying systems which are human in origin and do not stem from the possible environmental sign value these objects may exhibit. Any perception is conceptualised according to the pre-existing conceptual frameworks that have evolved in the human mental traditions over the millennia.
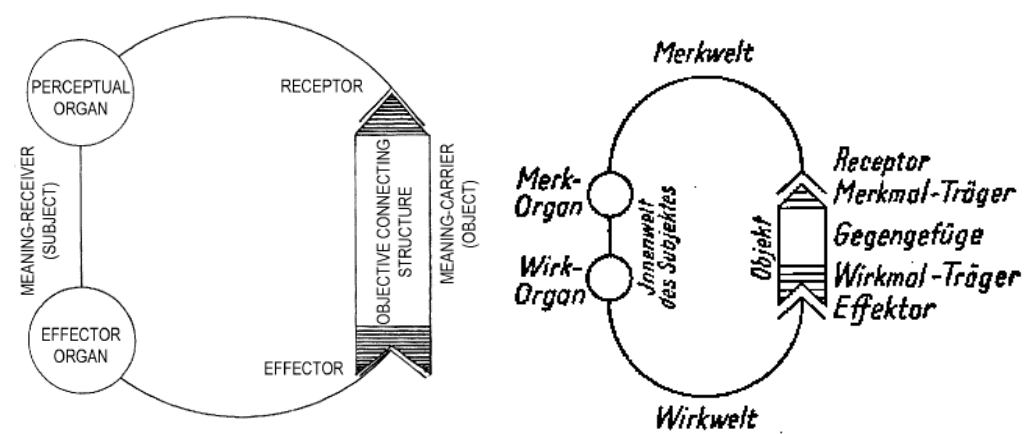

Figure 1. Uexküll's functional circle (Funktionskreis).

This process has various consequences. First, what for the "value" of nature in the context of our Umwelt? Kalevi Kull approaches the question from the perspective of biosemiotics (Kull 2001: 353-365). Naturally, all questions of value stem from a cultural ground. Here, we can clearly perceive how it is an exclusively cultural framework by which environmental issues are decided. From the perspective of the human, the question of value of nature is in truth the question of a part of his Umwelt, which turns out to be culture. The factual value of nature is in consequence removed to the sphere of the environment and cannot be judged as of the environment we only get a subjective impression. Second, as the mechanics of von Uexküll's functional circle show, each act of perception is followed by an act of effection on the 
environment. I should like to use this principle in my theory as follows: Since we strive for ever deeper knowledge of the environment, we turn more and more details of it into cultural concepts. Hence, by mere existing, but also by scientific reflection and investigation we are virtually "consuming" the environment, even if not exhausting it physically. The conceptualisation of nature reduces it to which is not yet known, as only the latter cannot yet be part of our conceptualised Umwelt. Third, the question of responsibility towards the environment/nature must be redefined. The ecological discourse has produced an awareness about protecting and saving the environment. This is essentially mistaken for nature. The ecologists cannot escape their cultural grounding: Responsibility for nature is connected with cultural concepts such as value, resources, rarities, etc. Hence, protection of the environment turns out to be a self-protective tendency of the human being in its Umwelt.

\section{Résumé: The ecological paradox}

I have seemingly arrived at a dead end: If everything is nature, and everything at the same time is culture, then where is the point of making a difference between the two in the first place? I should like to point out here that it is not the purpose of this paper to avoid terminological differences. The study of writing, of sports, and of architecture is different from the study of whales, of flowers, or of the planets. The former may clearly be attributed to culture, the latter to nature.

Still, we have come to think of whales as something "valuable", "precious". We have come to think of planets as something "worth to study", and flowers may represent "love", as the rose does, or mourning, or a thousand other sentiments. Anything can become a sign; any "natural" thing may become "culturalized". Hence, the natural resources may dwindle in substance, but they have long ceased to exist as a sign resource in themselves: They have become included in human culture.

The only true paradox is hence human beings engaging in a discourse on nature. As soon as nature becomes a topic of discourse, it is not nature any more, but a part of culture. This fact has been ignored by Lotman and others because they do not acknowledge the sign value of things beyond human signification. But the tree is worth while as a 
tree, as the growing thing which does not even bear a name. In Peircean terms: There is a natural thirdness of nature which enters our perception only by way of cultural firstness. Cultural thirdness then is the alienation of these sign values. The tree as the oak, birch, etc. in our biological sign systems has nothing to do whatsoever with that "tree" which is natural in itself.

I name this the ecological paradox. Even by discussing the measures to protect nature, we are diminishing it. We cannot escape it; the way of human signification dictates that semiosis results in symbols, or thirdness. However, by acknowledging this process, and possibly deconstructing it, we may be able to go beyond the nature of our culture and see that there is a different, alien, but quite real culture of nature. Both form the unity of the universe, and nurture each other. Let us appreciate this holistic perspective, to which semiotic opens a door. The necessity of abandoning old notions such as the threshold thinking, as well as reconsidering our notion of what nature, culture, and the environment truly are, lies only at the beginning of that process. Uexküll and Peirce offer us tools to chart anew our semiotic sphere and gain a better perspective. The two key concepts are continuity of semiosis and semiotisation of the environment.

\section{References}

Appadurai, Arjun (ed.) 1986. The Social Life of Things. Cambridge: Cambridge University Press.

Augustine, Aurelius 1952 [397]. On Christian doctrine. (Shaw, J. F., trans.) In: St. Augustine, Confessions... Chicago: Encyclopedia Britannica, 619-698.

Bockrath, Franz (ed.) 2001. Vom sinnlichen Eindruck zum symbolischen Ausdruck - im Sport. Hamburg: Czwalina.

Csikszentmihalyi, Mihaly; Rochberg-Halton, Eugene 1981. The Meaning of Things: Domestic Symbols and the Self. Cambridge: Cambridge University Press.

Deely, John 2001. A sign is what? A dialogue between a semiotician and a wouldbe realist. Sign Systems Studies 29(2): 705-743.

Douglas, Mary; Isherwood, Baron 1982 [1979]. The World of Goods. New York: Norton.

Eco, Umberto 1976. A Theory of Semiotics. Bloomington: Indiana University Press.

Friedrich, Georg (ed.) 2001. Zeichen und Anzeichen - Analysen und Prognosen des Sports. Hamburg: Czwalina.

Greimas, Algirdas Julien 1966. Sémantique structurale. Paris: Larousse. 
- 1987. On Meaning: Selected Writings in Semiotic Theory. London: Frances Pinter.

Hietzge, Maud Corinna (ed.) 1997. Semiotik des Sports [= Zeitschrift für Semiotik 29]. Tübingen: Stauffenburg.

Hildenbrandt, Eberhard (ed.) 1997. Sport als Kultursegment aus der Sicht der Semiotik. Hamburg: Czwalina.

Kull, Kalevi 2001. Biosemiotics and the problem of intrinsic value of nature. Sign Systems Studies 29(1): 353-365.

Lotman, Juri M. 1981. Kunst als Sprache: Untersuchungen zum Zeichencharakter von Literatur und Kunst. Leipzig: Reclam.

- 1990. Universe of Mind: A Semiotic Theory of Culture. Bloomington: Indiana University Press.

Martinelli, Dario 2002. How Musical is a Whale? Towards a Theory of Zoomusicology. (= Approaches to Musical Semiotics 3.) Helsinki: International Semiotics Institute at Imatra.

Nöth, Winfried 1990. Handbook of Semiotics. Bloomington: Indiana University Press.

- 2000. Handbuch der Semiotik. Stuttgart: Metzler.

- 2001. Protosemiotics and physicosemiotics. Sign Systems Studies 29(1): 1326.

Nöth, Winfried; Kull, Kalevi (eds.) 2001. The Semiotics of Nature. [= Sign Systems Studies 29(1).] Tartu: Tartu University Press \& Kassel: Kassel University Press.

Peirce, Charles Sanders 1931-1958. Collected Papers, vols. 1-6 (Hartshorne, C.; Weiss, P., eds.); vols. 7-8 (Burks, A. W., ed.). Cambridge: Harvard University Press. [Cited as CP.]

Saussure, Ferdinand de 1986 [1916]. Cours de linguistique générale. Bally, Charles; Sechehaye, Albert (eds.). Paris: Payot.

Uexküll, Jakob von; Kriszat, Georg 1970 [1934]. Streifzüge durch die Umwelten von Tieren und Menschen. Frankfurt am Main: Fischer.

\section{От окружающей среды до культуры: аспекты непрерывности}

Концептуализация жизненного мира любого вида содержит в себе преобразование материи его окружения в категории, составляющие характерный для этого вида умвельт. В статье утверждается, что свойственное человеку стремление концептуализовать умвельт ведет к трансформации “природы” в “культуру”. Такая человеческая активность имеет как минимум два последствия, которых мы не можем избежать и которые влияют не только на наше восприятие окружающей среды, но и на наш способ теоретизировать о границе между природой и культурой или о так наз. семиотическом пороге. 
Во-первых, любое восприятие окружающей среды сразу “переводится” в терминах культуры. Во-вторых, какой бы ни была “природа", включение ее в дискурс культуры отгораживает ее от наших непосредственных ощущений.

\section{Keskkonnast kultuurini: Pidevuse tahud}

Mistahes liigi eluilma kontseptualiseerimine sisaldab tema keskkonnas leiduva aine ümberkujundamise kategooriaiks, mis moodustavad ta liigiomase omailma. Käesolev artikkel väidab, et inimlik taotlus kontseptualiseerida omailm ühtlasi tingimata transformeerib $\mathrm{nn}$. looduse $\mathrm{nn}$. kultuuriks. See inimlik aktiivsus omab möödapääsmatult kaht tagajärge, mida ei saa vältida, kuid mis omavad mõju mitte üksnes meie keskkonnatajule, vaid ka meie viisile teoretiseerida looduse ja kultuuri piiri ehk semiootilise läve üle. Esiteks, iga keskkonnataju saab otsemaid vaadeldavaks kultuurilistes terminites. Teiseks, milline iganes ka "loodus" pole, selle liitmine kultuuridiskursusesse lahutab ta vahetust tunnetusest. 